\title{
Prospects of Islamic Banking in Nigeria: An Overview of Islamic Financial Theories of Al-Hayat Relief Foundation to Grassroots Economic Development.
}

\author{
${ }^{1}$ Salako Taofiki Ajani, ${ }^{2}$ Adepoju Razaq Idowu, ${ }^{3}$ Azeez Asif Olatubosun \\ ${ }^{1}$ Faculty of Major Languages Studies University Sains Islam Malaysia. \\ ${ }^{2}$ Tai Solarin University of Education Ijebu-ode, Ogun State, Nigeria. \\ ${ }^{3}$ Tai Solarin College of Education Omu-Ijebu, Ogun State, Nigeria.
}

\begin{abstract}
This paper attempts to have a brief look at the concept of Islamic Banking and little efforts that have been made to float Islamic banks and other Islamic financial institutions in Nigeria. The Nigerian Central Bank of Nigeria however has a standing policy prior to this time that non-interest banking or financial institutions could emerge but not to carry any religious connotations. (BOFIA) This has made it difficult for individuals and corporate bodies to float full fledge Islamic compliant banks or financial institutions in the country. A few who attempted it have gone into oblivion today, e.g. Habib Bank and Nigeria Arab Bank. Consequently, what the existing banks do is to open Islamic window as one of their products to cater for the teaming Muslim populace who are reluctant to patronize these banks because of their Islamic belief. This development has led some concerned Muslim individuals and groups to attempt to champion the course of Islamic financial theories in this regards operating under different names to avoid being subjected to government policies which may not be in line with Shariah principles. A few of these groups are Al-Hayat Relief Foundation, Ijebu-ode, Assalam Foundation, Al-Ansar, etc. This paper therefore intends to evaluate the contributions of Al-Hayat Relief Foundation to grassroots economic development with a bid to $x$-raying the areas of strengths and weaknesses in Islamic financial theories, more so that the foundation is at the verge of establishing an Islamic Micro finance Bank.
\end{abstract}

Keywords: Islamic financial theories, Al-Hayat Relief Foundation, grassroots empowerment.

\section{Introduction}

The title of this paper: Prospects of Islamic Banking in Nigeria has been so over flogged in the country and Nigerians seem to be paying lip service to its practical implementation. A lot of theories have been postulated as to the challenges and prospects of Islamic Banking in the country. There seems to be no practical approach to its implementation. According to Sule Ahmed Gusau, there is nothing new about the idea of Islamic Banking. It has been in the literature over 60 years and many volumes have been written in that respect. (Gusau 1993) [1]. To him, what is new is applying the concept to a vast territory like Africa with its diverse ethnic groups, races, colour and religion.

A few moves which have been made to initiate little practical operations have been stalled by Nigerian government policies which are not favourable to the whimps and caprices of Islamic Banking. For instance, Jaiz International Plc made a giant stride about ten years ago to make a bold move in this direction. [2]. Jaiz went as far as selling shares to Nigerians, individuals and corporate bodies to raise fund to meet the Central Bank of Nigeria condition which has been changed over times. Barely a year ago, Jaiz was issued a license to commence operation after about its ten years of establishment because of the Nigerian environment which is believed not suitable for Islamic Banking. This approval has been greeted with stiff opposition by a few Nigerians who viewed the approval as an attempt to Islamize Nigeria and Nigerians. The media houses could not be spared from this outcry. Some non-Muslims oppose the idea vehemently on religious ground whereas there is the Islamic Bank International of Denmark which is thriving well in a non -Muslim environment. (Gusau 1993) [3]. And this has not turned Denmark into an Islamic state or all the customers patronizing the bank to Muslims.

\section{Background to this topic.}

Interaction with members of our immediate environment still shows that a large number of Nigerians lack the knowledge of Islamic economic theories and this makes them to always oppose its introduction and implementation in the country. Hence, there is the need to put the concept in the right perspective. 


\section{Concept of Banking.}

According to Advanced Learners Oxford Dictionary, Bank is an establishment for keeping money and valuables safely. [4]. Services rendered by bank in conventional way are: savings, financing projects, giving out loans on interests basis, carrying out housing schemes and the likes. Tajudeen Sekoni (2012) [5] defines banking as the provision of broad range of financial services to the people to help them take up new opportunities and engage in productive ventures.

However, the interests charged on loans given out to individuals and corporate bodies and the bottle neck associated with the loans have been a bone of contention in the growing economy like Nigeria. The interests charged on loans have been the bane of all our problems in Nigeria and have dastardly affected our economy. Gusau (1993) [6] expresses the view that banks and companies in Africa since their inception during the colonial era based their investment operations on norms which are devoid of ethical philosophy. The operational methodologies of these banks and companies are not subjected to any moral value and their ultimate objective is to achieve gains no matter whether tools and methods employed conform to ethical axioms cherished by the society or not.

Individuals and corporate bodies who think they can make enough money on interests prefer to lodge their money in fixed accounts where interests will accrue on them without using the money to do anything. The resultant effect of this is that, large sum of money that could have been used in creating jobs by individuals and corporate bodies have been indolent. This results in high rate of unemployment in Nigeria and because many young and able bodied Nigerians have no work to do, some of them have turned to armed robbers, some to hired assassins and some to professional prostitutes.

Hence, money circulates among few individuals who monopolize the economy, exploit others and oppress their subordinates because of the high interest which they have to pay on the money loaned from the banks. This has led to corruptive practices among the young and the old, because the system further enriches the rich and impoverishes the poor. These atrocities are so enormous that one cannot exhaust the list. Gusau [7] opines that investment philosophy of African banks and companies concede elements of deceit and exploitation and so hoarding and all forms of usurious dealings characterize the western economic institutions. Victoria Duff (2012) [8] also expresses the view that interest causes rise in asset prices and cost of living.

\section{Islamic Banking.}

Bank in the Islamic terminology is seen as an establishment where money and valuable properties are kept for safety. Azeez (2007) [9] defines bank as an establishment for keeping money and valuables while banking is a business of running a risk. Uzair according to Azeez sees bank as important financial institutions that mobilize savings and idle funds in an economy and makes them available to those who can make better and fuller use of them. (Azeez 2007). [10]. Sekoni (2012) is of the opinion that services which bank renders include credit, savings, investment opportunities and money transfers. (Sekoni 2012). [11].

Like the Western Banks, the Islamic Banks equally carry out similar services. Services rendered to people are paid for by the people in the Islamic banks. One major difference between the Islamic banks and western type of banking is the issue of interest or usury which western banks charge on money loaned out to people which Islamic banking abhors. This is based on the verse of the Quran where Allah says "interest is unlawful and trade is lawful" (Quran 2; 275). [12]. A confusion arises here where majority of the people confuse interest as profit made on money invested. It has to be pointed out that interest is what is charged on loan or borrowings while profit is the surplus made on sales and business transactions.

Islamic law does not allow trading in currency for currency i.e. a situation where one gets \#5 and sells it for \#6 to make \#1 profit for whatever reasons. This practice will make money to be idle, encourage laziness, promote hoarding, aggravate inflation and may lead to eventual famine or shortage of food and essential commodities in any society. It may also lead to the loss of the value of the currency of the nation where more money in one nation may have less value in other nations. Supporting this, Roshash (1993) says, Islamic investment is devoid of deceit, dishonesty, ambiguity, usury and exploitation. [13]. Usman (2012), also supports that interest causes injustice among the people. [14].

Islamic banking in an attempt to curb these evils, promotes trading, investments on business and agriculture and giving out loans on interest free basis to enable people work conscientiously for the money collected with less anxiety of paying back any accumulated interest. The issue of giving out loan on interest free basis is what many of our people see as utopian which can never work in an environment like Nigeria. It is on this premise that one has fashioned out a topic like an Overview of Islamic Financial Theories of Al-Hayat Relief Foundation as an experiment of Islamic financing currently going on in Nigeria contributing to grassroots economic development.

This foundation has attempted to practicalize some Islamic financial theories in its fifteen years of existence which has proved that Islamic banking can thrive in Nigeria irrespective of all odds. Al-Hayat Relief Foundation was established on March 15th 1997, registered with the Corporate Affairs Commission as a 
foundation in the year 2000 with Registration No CAC /IT/NO 18559. The foundation has as its objectives to carry out all the pillars of Islam and more importantly to champion the course of Islamic economic system and to grant interest free loans to registered members of the foundation. Presently, the foundation has 38 branches across Ogun, Lagos, Oyo, Osun, Ondo, and Kwara states of the federation with a population of about 5500 members.(AGM report 2012). [15].

\section{Al- Hayat Relief Foundation Organogram. \\ Almighty Allah. \\ Board of Trustees (BOT). \\ National Executive Council (NEC). \\ Branch Executive Council (BEC). \\ Grassroots members. (GM).}

\section{Al- Hayat Relief Foundation Organogram.}

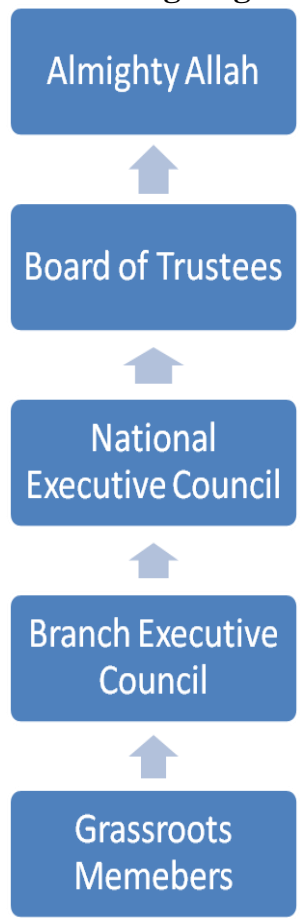

The grassroots members are responsible to branch executive council, branch executive council members are responsible to national executive council, national executive council members are responsible to board of trustees and members of the board of trustees are responsible to Allah.

Products of the foundation: The foundation carries out the following among members:

1. Interest free loans.

2. Self Development Interest free loans scheme.

3. Takaful- Self Managed Group Life Insurance scheme.

4. Murababah - Cost + Profit trading business scheme among members.

5. Musharakah - Partnership business scheme among members.

6. Mudarabah - Entrepeunership Yat Water factory scheme.

7. Housing scheme for members. 


\section{Products or Services enjoyed by members of the foundation.}

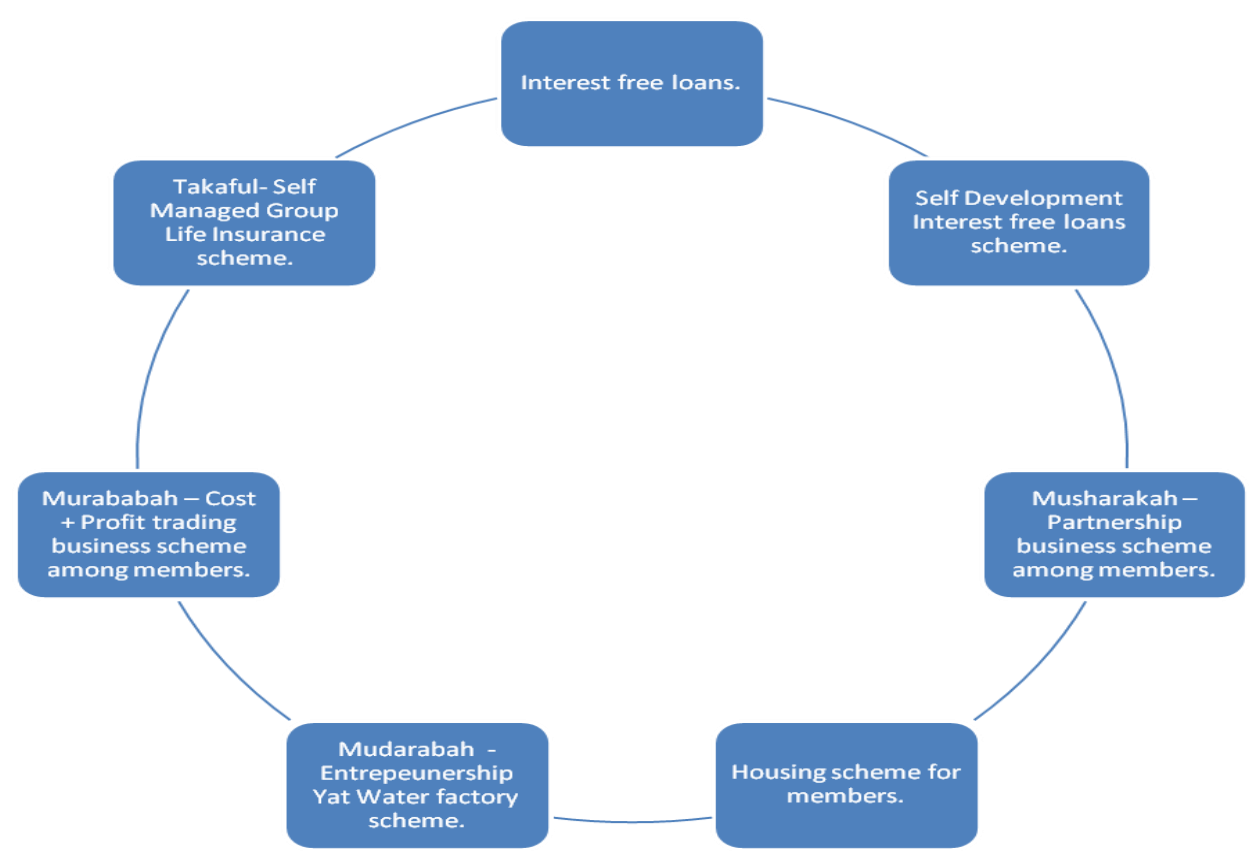

Interest free loans: Members enjoy interest free loans to the tune of one million naira. Loans between $\# 1000$ and \#200,000 are repaid within twenty months; loans between \#200,000 and one million naira are repaid within thirty months. Also, members enjoy Self Development Interest free loans of \#20,000 payable within ten months. Loans above \#200,000 attract the bank transaction charge of COT/VAT depending on the amount charged by the bank on the varied amounts of loans granted by the foundation. Total loan issued to members in the last financial year was \# 289,626,885.00 purely on interest free basis for personal and commercial developments. (Audited account 2012). [16].

Takaful: The foundation manages a Group Life Insurance Programme for members for initial five years. Members pay a premium of \#1000 per year and on eventual death of a member, the foundation gives a compensation of between $\# 20,000$ and $\# 60,000$ to the relatives of the deceased depending on the number of years for which the member had paid premiums to the foundation. As at $31^{\text {st }}$ March 2012, total premiums paid by members to takaful fund was \#10,051,000.00. Part of this money was invested on Murabahah business and other business projects which generated a profit \#1,308,200.00. Indemnity paid so far to the relatives of deceased members was \#820,000. With this, it was observed that the main takaful fund remains intact. (AlHayat Takaful account 2012). [17].

Mudarabah--Yat Water Factory: The term Mudarabah according to Muhammad Sharif Chaudhry (2003) [18] is seen as a special kind of business partnership where one partner gives money to another for investing it in a commercial enterprise. This investment comes from the first partner who is called Rabbul mal while the management and work is an exclusive responsibility of the other, who is called "Mudarib". Partners in this sense may involve more than two people. The foundation attempted this by selling shares to members to raise fund for the establishment of a pure water factory in the year 2009. About ten million naira was raised for this project which has since commenced production about three years ago. Shares bought for this project is for life. Proceed from this share is to enhance financial income of members and to secure the future financial sustainability of members' children.

Housing scheme: The foundation also acquired about 23 acres of land at Ilefun along Iperin Ijebu ode, Ibadan Road. No loan was taken to finance this gigantic project in an era when people believe that such a project could not be achieved without taking interest loan. Branches subscribed to acquire the land and work is gradually commencing on the area. The aim of embarking on this project is to make Al-Hayat members become private owners of their houses without getting involved in interest mortgaging housing schemes.

Business scheme: Business is the life wire of AL-Hayat Relief Foundation. The foundation runs Murabahah - cost + profit type of business and Musharakah - Partnership business, rental, transport and a host of others to generate money. [19]. Profits made are shared among members annually based on the amount of shares they have in their share accounts. 
Al-Hayat activities are operated at two levels: [i] National level where the National Executive Council takes care of the branches.

\{ii Branches level - where the branches take care of individual members at the grassroots levels. The foundation uses the branch levels to get to the grassroots where the needs of individual members would be met and catered for.

\section{Challenges Facing the Operation of Islamic Financial Theories in a Growing Economy.}

Challenges facing AL-Hayat Relief Foundation in its fifteen years of operation could serve as eye - opener or test grounds for Islamic financing in Nigeria and elsewhere.

[a] Defaulters on Loans: A few percentage of members does not pay back loans taken or business finances as at when due. This sometimes delays other intending loan seekers or business participants to get theirs on time. To solve this problem, the foundation put debt recovery committee in place to address this issue and this has done wonders because it is helping in reducing the problem. It is important to note that Al-Hayat Relief Foundation has not recorded any bad debt in its past fifteen years of operation.

[b] Betrayal of Trust: Trust and sincerity are great elements in Islamic financing. Some leaders betray the trust repose in them, they become insincere and act against the oaths they took before Allah and members by mismanaging the money put in their care and using it to their personal advantage. Such leaders where detected are immediately removed from office and are made to pay back the money mismanaged. A particular case is worth mentioning here of a chairman of a branch who mismanaged about 1.207million naira in the 2009 - 2010 financial year. The foundation's lawyer was charged with the responsibility of charging him to court. The case is still in court and the chairman has been paying back the money mismanaged. Some lessons were learnt from this development and measures have since been put in place to curb a repetition of similar occurrence.

[c]_Misconception of Islamic Economic Theories: A large number of members still have wrong perception of Islamic finances. They conceive the western economic practices as same with Islamic finances which are not parallel to each other. What the leadership of the foundation does to correct this impression and wrong notion is to organize seminars, lectures, workshops and training for members to educate, enlighten and re- orientate their psyche to Islamic finances.

[d] Lack of Islamic Financial Experts: Another challenge facing the foundation is the inability to have enough Islamic financial personnel to work in key posts. This has made it difficult for the foundation to meet demands for request of more branches. It is the foundation's practice to send an expert to build a new branch in a unique way for at least a duration of two years. It is a big challenge to get personnel for Islamic financing in Nigeria presently.

[e] Bank Policies and Regulations: The foundation faces a little challenge from her bankers. The foundation does not have a bank of its own as at now, the foundation's asset is about \#334,048,358.00, and the foundation gives out loans through these banks. For instance, in the last financial year that ended March 2012, the consolidated account of all the branches revealed that a total sum of \#289,626,885.00 interest free loan was given out to members. Most of these banks charged COT and VAT on cheques issued to members amounting to \#910,183.This was the amount paid to banks even when the foundation gave out interest free loans. There is no doubt that if the foundation had Islamic bank, the challenge will be easily overcome for it will serve as clearing house for all the existing members of Al-Hayat Relief Foundation.

[f] Account Policies / Auditing: Al-Hayat account is audited by audit firms which have western background. This has always posed some challenges as they subject the accounts to all the rudiments of unIslamic principles. Efforts to make western auditors align towards Islamic accounting procedures have always been hectic because they lack knowledge in this area and it has become difficult to get a template of Islamic accounting which would be devoid of any western influence. Specific areas of contention are issues of depreciation of fixed assets like land, building, and machinery. In the last financial year for example, the auditors adopted the following depreciation rates:

Land and Building $2 \%$

Furniture and Fittings $10 \%$

Motor Vehicle 20\%

Office Equipment $\quad 10 \%$ 
The implication of this depreciation on the overall account as presented under appendix was that it reduced the profit to be shared among member share holders whose money were invested on different businesses. The auditors found it difficult to demarcate between depreciation of lands and buildings whereas all experts support that lands should not be depreciated. [20].

[g] Developmental loan from Islamic Banks: Another area of focus is the fact that Islamic finances do not make provision for developmental loans except provision for businesses. How do we cater for cases of one who wants to take loan for personal development such as loan to acquire education or loan to foot medical bill and the likes? This has been another area of challenge to be addressed in Islamic financing. Islamic banks and financial institutions seem not to make provision for this aspect. What is partially related to this is Qard hassanah known as benevolent loan but most Islamic banks and financial institutions do not have provision for this.

\section{Prospects of Islamic Financial Theories in a Developing Economy.}

The previous years of AL- Hayat Relief Foundation's practical experiences have shown that Islamic financial theories can flourish and thrive well in a country like Nigeria and elsewhere and it could help in improving a growing economy. Experiences reveal that a higher percentage of the people will be willing to cooperate if the suitable environment and good leadership are provided and the following could be achieved.

\section{Prospects of Islamic Financial Theories in a Developing Economy.}

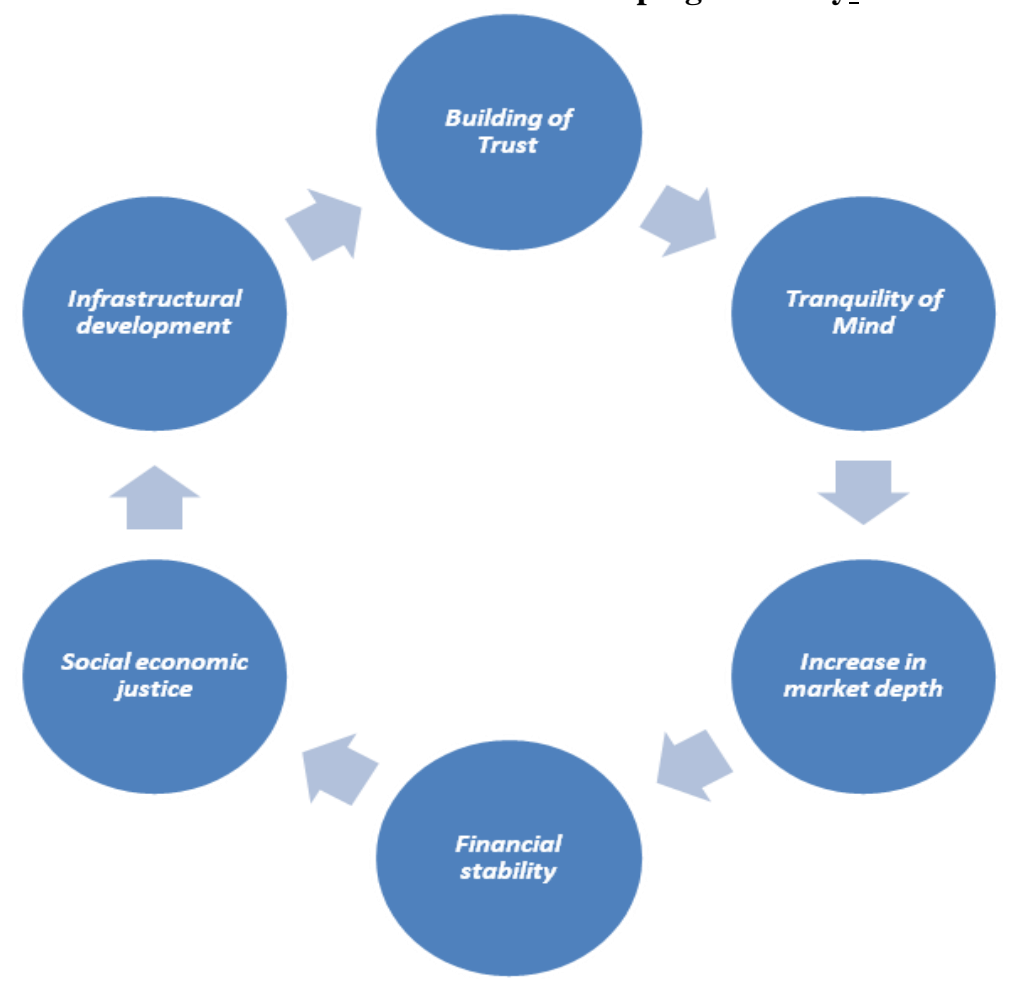

a. Building of Trust / Transparency: Islamic financing is aimed at the building of trust. This can be guaranteed where transparency is exhibited. Good leadership by example could help realize this goal and help build trust in the leadership and followership.

b. Tranquility of Mind: Islamic banking will promote tranquility of mind in the sense that loanee will have little anxiety which characterize interest loans of the western banking system. This is because no interest would be charge on loan collected and respite is enjoyed by the borrower.

c. Increase in market depth: Islamic banking will assist in the creation of more job opportunities. This is because before loans are granted or businesses approved, the bank which is not after interest alone but also after the utilization of loans and after easy ways of paying back will guide and advise loanee before taking up loans. The Islamic bank will also monitor that the loan is judiciously used or that the business mutually monitored. 
d. Financial stability: Possibility of hiking price will be reduced to the barest minimum. This is because loans taken if invested on a business, the loanee will not have to pay a dine above the amount of loan collected but the target would be profit sharing. So, it will assist in creating a stable economy.

e. Social economic justice: Islamic banking will take care of low income traders since the priority is not to make interest but to build the citizenry economically. It will make the economy grow because the individual economy contributes to the societal economy. It will assist in getting in touch with people at the grassroots level, it will discourage monopoly of business transactions, breaks up hoarding of essential commodities by a few individual and it will make development direct to all and sundry.

f. Infrastructural development: It will boost infrastructural development in the sense that it will attract both local and foreign investors which will contribute to national economic development which is the focus of Islamic financial theories. [21].

\section{Suggestion}

It is hereby suggested that a blue print of Islamic accounting model be fashioned out which would serve as guide for Islamic financial institutions. There is need to intensify efforts in the area of practical implementation of Islamic financial theories to enhance the growth of Islamic economy with the aim of moving forward Nigeria's economic development.

\section{Conclusion}

Nigeria is a democratic country where people have freedom of religion and freedom to do everything that is lawful. It also has a growing economy; hence giving chance to the operation of Islamic financial theories alongside western economic theories will help in making the economy grow. Government should provide suitable and conducive level play grounds for all in the banking industry to thrive. Uniqueness of Islamic financial theories should be put into consideration when formulating policies and setting standards and guidelines for intending banking operators and financial institutions in the country.

\section{References.}

[1]. Gusau, S. A. 1993. "Islam in Africa". Proceedings of the Islam in Africa Conference. (Editors). Nura Alkali, Adamu Adamu. Spectrum books Ltd. Sunshine House, Ibadan, Nigeria. pp. 354-363.

[2]. Jaiz International Plc. 2006. Private Placement Memorandum. http://jaizbankplc.com/about-us.aspx

[3]. Gusau, S. A. 1993. "Islam in Africa". Proceedings of the Islam in Africa Conference. (Editors). Nura Alkali, Adamu Adamu. Spectrum books Ltd. Sunshine House, Ibadan, Nigeria. pp. 354-363.

[4]. Hornby, A.S. 2001. Oxford Advance Learner's Dictionary. $6^{\text {th }}$ Edition. Ibadan :Oxford University Press.

[5]. Sekoni Tajudeen. 2012. "Interest Free Banking: Investment and Profitability". Guest Lecture delivered at Al-Hayat National Annual General Meeting Held at Otunba Dipo Dina Stadium Ijebu-ode, June $17^{\text {th }}, 2012$. np.

[6]. Gusau, S. A. 1993. "Islam in Africa". Proceedings of the Islam in Africa Conference. (Editors). Nura Alkali, Adamu Adamu. Spectrum books Ltd. Sunshine House, Ibadan, Nigeria. pp. 354-363.

[7]. Gusau, S. A. 1993. "Islam in Africa". Proceedings of the Islam in Africa Conference. (Editors). Nura Alkali, Adamu Adamu. Spectrum books Ltd. Sunshine House, Ibadan, Nigeria. pp. 354-363.

[8]. Duff Victoria. 2012. "What Are the Negative Effects of Low Interest Rates". www.ehow.com, assessed on 03/11/2012

[9]. Azeez, A. O. 2007. "Prospects of Islamic Banking System in Nigeria. (Editors). Muhibbu-din M.A, Lawal I.A Al-Hadarah-LASU Journal of Arabic and Islsamic Studies. Department of Religions, LASU Ojo, Lagos. pp. 49-63.

[10]. Azeez, A. O. 2007. "Prospects of Islamic Banking System in Nigeria. (Editors). Muhibbu-din M.A, Lawal I.A Al-Hadarah-LASU Journal of Arabic and Islsamic Studies. Vol. 7. Department of Religions, LASU Ojo, Lagos. pp. 49-63.

[11]. Sekoni Tajudeen. 2012. "Interest Free Banking: Investment and Profitability". Guest Lecture delivered at Al-Hayat National Annual General Meeting Held at Otunba Dipo Dina Stadium Ijebu-ode, June $17^{\text {th }}$, 2012. np.

[12]. Ali, A.Y. 1989. The Holy Qur'an: Text, Translation and Commentary. Maryland: Amana Corporation.

[12]. Onafowokan, O. 2004. Non-Interest (Islamic) Banking. Lagos, Nigeria. Kings \& Queen Associates.

[13]. Roshash, M. A. 1993. "Islam in Africa". Proceedings of the Islam in Africa Conference. (Editors). Nura Alkali, Adamu Adamu. Spectrum books Ltd. Sunshine House, Ibadan, Nigeria. pp. 336-353.

[14]. Usman, M. T. 1998. An Introduction to Islamic Finance, Part II, Karachi.

[14]. Usman T. 2012. "The adverse effects of interest on society". www.islamibanking.com, assessed on 03/11/2012.

[15]. Al-Hayat Relief Foundation. 2012. "National Annual General Report 2012". np.

[16]. Al-Hayat Relief Foundation. 2012. "Audited Consolidated Account 2012". np.

[17]. Al-Hayat Relief Foundation. 2012. “Al-Hayat Takaful Account 2012”. np.

[18]. Chaudhry, M. S. 2003. Fundamentals of Islamic Economic System. http://www.muslimtents.com/shaufi/b16/b16_13.htm

[18]. Abu Dhabi Islamic Bank, 2009. "Mudarabah", www.adib.ae/web/guest/corporate-banking/mudarabah.

[18]. BizTree.com, 2006. "Mudarabah: Concepts in Islamic Economics and Finance". cief.wordpress.com/2006/04/02/mudarabah

[18]. Islamic Finance.com, 2009. "Mudarabah and Masharakah". www.islamic-finance.com

[19]. Usman, M. T. 1999. An Introduction to Islamic Finance, Part One. Somolu, Lagos, S. A. Al- Aminu Publications.

[20]. Accounting Policies. 2007. Land Depreciation, Human Sciences Research Council Annual Report March 2007.

[21]. Sekoni Tajudeen. 2012. "Interest Free Banking: Investment and Profitability". Guest Lecture delivered at Al-Hayat National Annual General Meeting Held at Otunba Dipo Dina Stadium Ijebu-ode, June $17^{\text {th }}, 2012$. np. 
Appendix.

Al-Hayat Consolidated Account for the Financial Year April 2011 - March 2012.

\begin{tabular}{|c|c|c|}
\hline INCOME & $2010 \backslash 2011$ & $2011 \backslash 2012$ \\
\hline Admission formlMembership form & 676,610 & $\mathbf{9 6 0 , 5 3 7}$ \\
\hline Loan and SDS Form & 217,605 & 284,030 \\
\hline Donation Received & 236,785 & 411,275 \\
\hline Development levy & $\mathbf{1 , 8 0 0 , 2 2 0}$ & $2,766,870$ \\
\hline Lateness, Apology \& fine fees. & $\mathbf{5 8 9 , 8 2 0}$ & 679,745 \\
\hline Identity Cards & 346,715 & 295,500 \\
\hline Files & 16,350 & 126,950 \\
\hline COT paid by Members & 334,249 & 604,917 \\
\hline NEC Dues & $\mathbf{4 5 8 , 4 4 0}$ & 410,620 \\
\hline AGM fees & $1,655,620$ & $3,066,710$ \\
\hline Zakat \& Sadaqah( Net) & 274,923 & 785,605 \\
\hline Net Business Income & 162,569 & $7,489,407$ \\
\hline Other Income & $\mathbf{8 2 1 , 8 3 5}$ & 441,512 \\
\hline SUBTOTAL & $7,591,741$ & $18,323,677$ \\
\hline EXPENDITURE & - & - \\
\hline Telephone Services & $\mathbf{1 2 9 , 9 9 5}$ & $\mathbf{1 1 7 , 9 0 5}$ \\
\hline Stationery $\backslash$ Photocopies & 280,805 & 526,665 \\
\hline Transport \& Travelling & 183,220 & 248,690 \\
\hline Bank Charges & 713,052 & 910,183 \\
\hline Entertainment & 90,390 & 87,875 \\
\hline Salaries \& Allowances & 535,750 & 808,850 \\
\hline Donation \& Gift & 24,790 & $\mathbf{1 7 2 , 5 8 5}$ \\
\hline Office \& General & 180,545 & 333,925 \\
\hline Depreciation & 619,388 & 862,128 \\
\hline Repairs \& Maintenance & 99,230 & $\mathbf{1 7 2 , 6 0 0}$ \\
\hline NEC Dues & 465,060 & 814,502 \\
\hline Provision for Bad Debt $(.05 \%)$ & 634,963 & 982,663 \\
\hline Bad Debt written off & 37,601 & - \\
\hline Admission form (Purch) & 411,450 & 656,530 \\
\hline Files \& I.D Cards & 269,630 & 440,260 \\
\hline AGM Expenses & $\mathbf{1 , 8 8 6 , 6 8 5}$ & $3,273,140$ \\
\hline Rent \& Rates & 309,008 & $\mathbf{3 2 8 , 8 1 0}$ \\
\hline Electricity & 32,225 & $\mathbf{3 9 , 3 1 0}$ \\
\hline Fuel for Generator & 41,985 & 82,050 \\
\hline Zakat \& Sadaqah( NEC) & $\mathbf{1 7 7 , 1 7 7}$ & 287,219 \\
\hline Insurance Dimunition & 3,500 & 2,000 \\
\hline Training \& Seminars & $\mathbf{7 9 , 5 0 0}$ & $\mathbf{1 2 7 , 0 1 0}$ \\
\hline ON-LINE REG. & 38,400 & $\mathbf{7 5 , 3 0 0}$ \\
\hline Loss $\backslash$ fraud & - & - \\
\hline Rent (Amortised) & 32,400 & - \\
\hline National Secretariat & 42,410 & 279,050 \\
\hline SUBTOTAL & $7,319,159$ & $11,629,250$ \\
\hline Net Surplus & 272,582 & $6,694,427$ \\
\hline TOTAL & $7,591,741$ & $18,323,677$ \\
\hline APPROPRIATION & - & - \\
\hline Net Surplus B/f & $(\mathbf{1 5 3 , 0 6 4 )}$ & $6,810,400$ \\
\hline Profit Sharing & $1,445,246$ & $(5,107,800)$ \\
\hline Honorarium & 386,913 & $(1,364,987)$ \\
\hline Reserve Funds & $1,046,245$ & $(340,520)$ \\
\hline \multicolumn{3}{|c|}{ BALANCE SHEET AS AT 31ST MARCH,2012 } \\
\hline ASSETS & $2010 \backslash 2011$ & $2011 \backslash 2012$ \\
\hline Land and Building & $6,535,910$ & $7,118,950$ \\
\hline Motor Vehicle & 647,604 & 647,604 \\
\hline Furniture and fittings & $\mathbf{1 , 5 6 8 , 2 0 1}$ & $2,892,418$ \\
\hline Office Equipment & 581,015 & $\mathbf{1 , 7 9 6 , 1 7 5}$ \\
\hline Shares in Jaiz & 675,200 & 818,667 \\
\hline Shares in Yat & $2,581,720$ & $2,409,560$ \\
\hline Shares in Golden Estates & $7,591,000$ & $6,374,000$ \\
\hline Shares in NEC & 825,000 & $1,115,920$ \\
\hline Savings in NEC & $1,249,200$ & $1,616,400$ \\
\hline Investment on Business & $1,263,196$ & $1,735,436$ \\
\hline Investment on Stocks & $1,365,200$ & $1,408,000$ \\
\hline Insurance Premium - Paid to NEC & $6,672,250$ & $9,671,240$ \\
\hline Hajji \& Umrah - Paid to NEC & 319,000 & 240,550 \\
\hline
\end{tabular}


Prospects Of Islamic Banking In Nigeria: An Overview Of Islamic Financial Theories Of Al-Hayat

\begin{tabular}{|l|r|r|} 
Prepayment & $\mathbf{4 9 4 , 2 9 1}$ & $\mathbf{8 8 9 , 5 0 0}$ \\
\hline Outstanding loan & $\mathbf{1 2 6 , 0 0 8 , 8 0 0}$ & $\mathbf{2 0 2 , 9 4 8 , 5 7 0}$ \\
\hline SDS Outstanding & $\mathbf{4 , 1 1 6 , 8 6 0}$ & $\mathbf{5 , 2 1 4 , 4 0 0}$ \\
\hline Ileya Support & $\mathbf{8 , 7 1 8 , 9 2 3}$ & $\mathbf{1 0 , 1 7 9 , 7 9 5}$ \\
\hline Debtors (on business) & $\mathbf{3 1 , 1 0 7 , 5 5 3}$ & $\mathbf{4 4 , 3 9 3 , 7 3 3}$ \\
\hline Other Debtors & $\mathbf{1 , 0 2 5 , 6 5 3}$ & $\mathbf{1 , 2 8 9 , 6 5 6}$ \\
\hline Staff Dev.Loan & $\mathbf{8 1 0 , 2 3 0}$ & $\mathbf{3 , 2 1 4 , 6 3 0}$ \\
\hline Stocks & $\mathbf{3 5 0 , 9 3 5}$ & $\mathbf{1 3 6 , 0 9 3}$ \\
\hline Cash and Bank Balances & $\mathbf{2 1 , 2 6 6 , 7 2 3}$ & $\mathbf{2 7 , 9 3 7 , 0 6 1}$ \\
\hline TOTAL & $\mathbf{2 2 5 , 7 7 4 , 4 6 4}$ & $\mathbf{3 3 4 , 0 4 8 , 3 5 8}$ \\
\hline LIABILITIES & - & - \\
\hline Shares Capital & $\mathbf{4 1 , 5 4 7 , 2 2 5}$ & $\mathbf{6 0 , 1 8 7 , 8 8 3}$ \\
\hline Shares on Building Project & $\mathbf{3 , 2 1 8 , 7 0 0}$ & $\mathbf{3 , 0 0 5 , 9 0 0}$ \\
\hline Members Savings & $\mathbf{1 6 2 , 3 6 2 , 9 4 5}$ & $\mathbf{2 4 7 , 9 9 3 , 4 6 0}$ \\
\hline Children Savings (SEC) & $\mathbf{1 0 , 7 0 0}$ & $\mathbf{7 9 , 7 0 0}$ \\
\hline Ileya Saving Scheme & $\mathbf{1 , 0 7 7 , 2 7 0}$ & $\mathbf{2 , 0 1 1 , 4 9 0}$ \\
\hline Insurance Premium & $\mathbf{7 , 1 5 1 , 8 7 0}$ & $\mathbf{1 1 , 3 4 7 , 9 8 1}$ \\
\hline Other Target Savings & $\mathbf{2 8 3 , 1 0 0}$ & $\mathbf{2 6 0 , 7 2 2}$ \\
\hline Hajj \& Umrah & $\mathbf{8 , 5 0 0}$ & $\mathbf{5 0 , 8 5 0}$ \\
\hline Provision for Depreciation & $\mathbf{1 , 3 4 3 , 9 8 3}$ & $\mathbf{9 0 1 , 9 0 5}$ \\
\hline Provision for Doubtful Debt & $\mathbf{4 0 , 3 6 2}$ & $\mathbf{9 1 6 , 6 7 4}$ \\
\hline Profit Sharing & $\mathbf{3 , 3 1 6 , 8 1 2}$ & $\mathbf{5 , 1 0 7 , 8 0 0}$ \\
\hline Honorarium & $\mathbf{9 1 1 , 4 3 0}$ & $\mathbf{1 , 3 6 2 , 0 8 0}$ \\
\hline Reserve Funds & $\mathbf{2 , 6 6 1 , 6 4 4}$ & $\mathbf{3 4 0 , 5 2 0}$ \\
\hline NEC Arrears & $\mathbf{2 2 6 , 7 3 4}$ & $\mathbf{2 1 , 8 3 3}$ \\
\hline Accrual & $\mathbf{1 , 6 1 3 , 1 8 9}$ & $\mathbf{4 5 9 , 5 6 0}$ \\
\hline TOTAL & $\mathbf{2 2 5 , 7 7 4 , 4 6 4}$ & $\mathbf{3 3 4 , 0 4 8 , 3 5 7}$ \\
\hline & - & - \\
\hline Loan Released & $\mathbf{1 3 5 , 8 2 1 , 3 0 5}$ & $\mathbf{2 4 3 , 4 3 4 , 3 9 0}$ \\
\hline S.D.S. Released & $\mathbf{3 , 7 8 0 , 6 0 0}$ & $\mathbf{8 , 1 3 8 , 6 5 0}$ \\
\hline TOTAL & $\mathbf{1 3 9 , 6 0 1 , 9 0 5}$ & $\mathbf{5 2 3}$ \\
\hline PROFIT PER SHARE & & \\
\hline & & \\
\hline & & \\
\hline
\end{tabular}

